The Berkshire Conference of Women Historians will award its annual prizes for the best book and the best article in any field of history written by a woman and published during 1981. Submissions for the Book Award should be sent to: Jean Christie, 34 Bellingham Lane, Great Neck, NY 11023. Submissions for the Article Award should be sent to: Asunción Lavrin, Department of History, Howard Un iversity, Washington, DC 20059. Two copies of the book or article are required. Deadline for submission: February 1, 1982.

\title{
Child Development Project in Morocco
}

A project on child development, 1 iteracy and education in Morocco. A three-year project on children's acquisition of 1 iteracy in traditional (kuttab) and modern schools will begin in 1981 in both rural and urban settings in Morocco. The project is being organized jointly by Université Mohamed $V$ and the University of Pennsylvania. Individuals with the appropriate language skills (Maghrebi Arabic, Berber, French), and with an interest in doing fieldwork, are encouraged to respond. Persons interested in doing fieldwork for doctoral dissertations are particularly welcomed, as are persons of any nationality or either sex. Contact: Dr. Daniel A. Wagner, 714 Larsen Hall, Harvard University, Cambridge, MA 02138. Telephone: 617/495-3440.

\section{New Annual for Arabic Literature}

Mundus Arabicus (1981) is a new annual publication devoted to Arabic literature, edited by a group of scholars and bibliographers, among them:

- Fawzi Abdulrazak, Harvard College Library;

- Sal ih Jawad Altoma, Indiana University;

- Issa J. Boullata, McGill University;

- Muhsin S. Mahdi, Harvard University; and

- David H. Partington, Harvard College Library

The first volume is entitled: Arab Writers in America: Critical Essays and Annotated Bibliography. The forthcoming volume of Mundus Arabicus (1982) will be entitled: Arabic Literature in North Africa Since 1900. Publ ished by Dar Mahjar, Cambridge, Mundus Arabious (26 $\times 18 \mathrm{~cm}$.; iv, $274 \mathrm{pp}$. ), sells for $\$ 22.00$ plus $75 \mathrm{c}$ (regular postage) to individuals; and $\$ 30.00$ plus postage to libraries, institutions and organizations. Forward orders to: Dar Mahjar, P.0. Box 56, Cambridge, MA 02238 .

\section{Peasant Studies}

The University of Utah announces the resumption of publication of the quarterly journal, Peasant Studies, beginning with Volume IX, No. 1, in fall 1981. The previous eight volumes were produced under the sponsorship of the University of Pittsburgh.

The journal will continue to feature articles, extended review essays, and news and announcements of current research and conferences, focusing on contemporary and historical peasants and peasant societies. Contributions are invited from such diverse fields as anthropology, economics, geography, history, political science and sociology, as well as those drawing on interdisciplinary perspectives. 
Please submit all manuscripts (in duplicate) and inquiries to: Prof. Anand A. Yang, Editor, Peasant Studies, Department of History, University of Utah, Salt Lake City, UT 84112.

\section{NEWS OF SCHOLARS}

\section{Ph.D. Dissertations Completed}

Ali A. Masalehdan [U of Massachusetts, Amherst]: Political Culture and Political Development: An Analysis of the Institution Building Process in Iran.

Evelyn A. Menconi [Boston U]: An Analysis of Teachers' Perceptions of the Arab World.

Athena M. DeFabo [George Washington U]: The Aegean Island Question and Greece: A Diplomat ic History, 1911-1914.

Barbara Schmitz [New York U]: Miniature Painting in Harāt, 1570-1640. Michael J.L. Young [U of Melbourne, 1962]: The Arabian System of Medicine in the Thirteenth Century.

James G. Flynn [U of Melbourne, 1967]: St. Thomas' Use of Islamic Sources on the Nature and Attributes of God.

Terence C. Falla [U of Melbourne, 1972]: Studies in Peshitta Gospels: An Examination of Four Groups in the Peshitta Gospel Words and their Contribution to the Study of the Peshitta as a Revision.

Hanneh D. Deeb [U of Melbourne, 1975]: The Popular Proverbs of Lebanon. Ibrahim Ata [U of Melbourne, 1980]: The Lebanese Community in Melbourne.

Vincent A. Clark [U of Melbourne, 1980]: A Study of New Safaitic Inscriptions from Jordan.

Jeremy Salt [U of Melbourne, 1980]: Christian Imperialism in Turkey, 1876-1908.

\section{Dissertations in Progress}

Carol Bier [New York U]: Dionysiac Imagery in the Art of Iran.

Mary Maugham [U of Utah]: Retaliatory Raids and Terrorism: Tactics and Strategies in the Arab-israeli Conflict.

Hussein El-Khafaifi [U of Utah]: A Descriptive Analys is of Benghazi Arabic.

Mohammed Ben-Ghaly [U of Utah]: Comparative Study in Arabic and Persian Mystical Poetry.

Lida Andisheh [U of Utah]: Life and Work of Abbas lqbal Asht ${ }^{C}$ iani. Balkees, al-Najjar [U of Utah]: Aspectical Verbs in Kuwaiti Arabic. Abdulmatlub Abdulmatlub [U of Utah]: The Modern Libyan Short Story: A Comparative Study.

\section{Appointments and Promotions}

Yael Feldman - Assist. Professor of Hebrew Language and Literature, Columbia University, New York City.

Marlee Meriwether - Assist. Professor of History, Denison University. Willa Dawson - Lecturer, English Linguistics, Kuwait University. Hani Fares - [Kuwait U]: Visiting Professor, Institute of Islamic Studies, McGill University, 1981-1982.

David Ede - [W. Michigan U]: Visiting Professor, Inst. of islamic Studies, McGill University, 1981-1982.

John Damos

- Professor of Political Science, Portland Science University. 